\title{
Obituary
}

\section{Alan Haworth, OBE (UK), GDCS (Zambia), FRCPsych.}

Head, Psychiatry Service, University of Zambia, Zambia

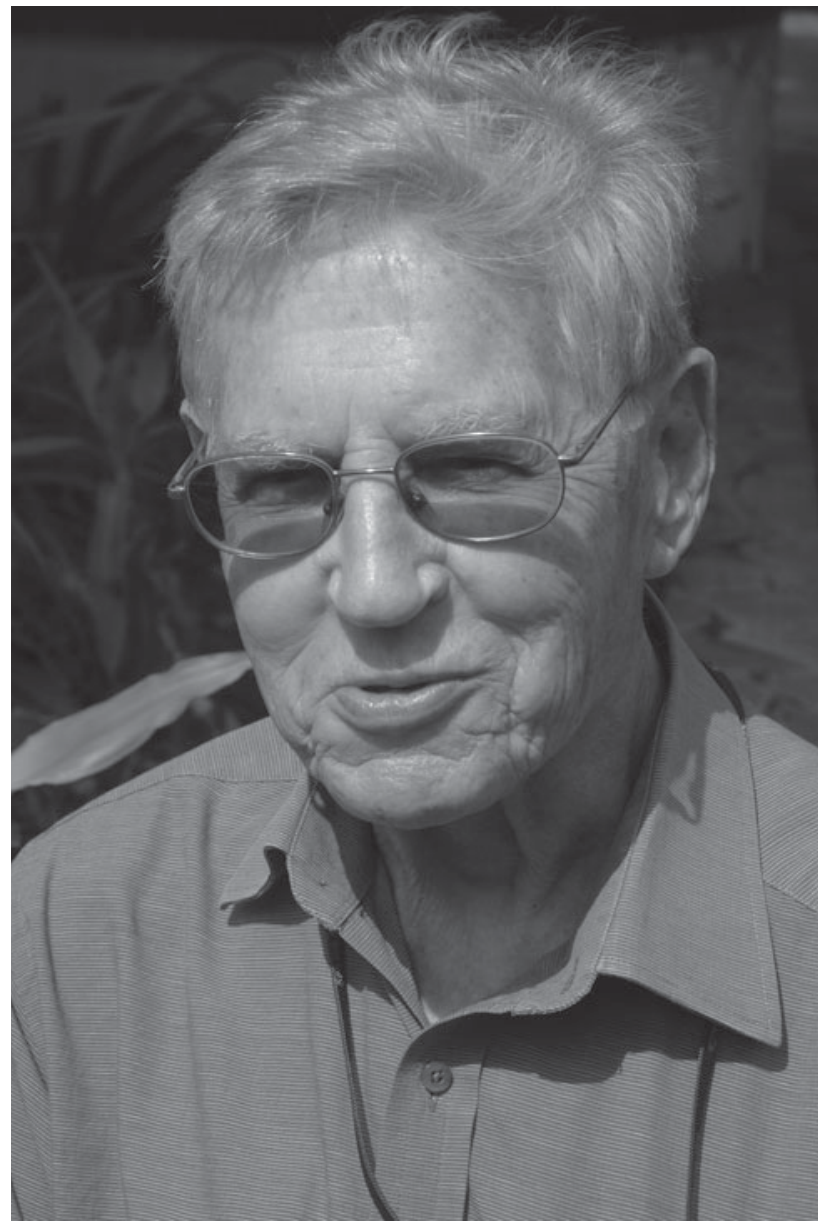

Alan Haworth, who died on 17 December 2017 at the age of 89 was a pioneering psychiatrist who, over a long period from 1964 until he retired in 2013, established psychiatric services in Zambia. Shortly after his death, the Zambian Minister of Health issued a statement describing him as 'the father of mental health among the medical fraternity of Zambia'. When he arrived in Zambia, first as a missionary doctor and shortly afterwards as a psychiatrist in the government medical service, the mental health services were extremely limited or, in most parts of the country, non-existent. Haworth took up government positions and had a pivotal role in setting up the mental health services of newly independent Zambia. Following this, he became Head of the Psychiatry Department at the University of Zambia. He set up the National AIDS Counselling Services Unit (at the National Mental Health Resource Centre $(N M H R C))$ and remained its head for 17 years. He was elected National President of the Zambian Red Cross.
Most importantly, as Chairman of the paramedical committee of the Medical Council of Zambia, he drafted a new Medical and Allied Professions Bill. This enabled the registration of paramedics after highly regulated training, and their substantial but controlled contribution to general healthcare in a country which, at the time, had only a fragmentary health service and hardly any higher educational facilities. Under Haworth's leadership, Zambia established its own medical school. This enabled a build-up of resources for supplying suitable workers at all levels and the establishment of a healthcare system modelled on the Alma Ata declaration on primary healthcare.

His second achievement was the development of a system for the provision of countrywide mental healthcare, integrated into primary healthcare, and ensuring that the training of various types of specialised workers could take place in close liaison with generic health workers. In an article published in 1988, he described the first 25 years of his experience as a psychiatrist in Zambia. ${ }^{1}$ This initially involved travelling around the country by air in an ageing Dakota for three weeks out of four, visiting medical facilities to establish mental health clinics. He developed a course for clinical officers in psychiatry who worked in communities around the country.

In 1972, he applied to the World Health Organization (WHO) for funding to enable him to visit universities in African countries. An invitation from the WHO to participate in a multicentre study of community response to alcohol-related problems seemed to be mapping a future area of specialisation, but the advent of AIDS in Zambia forced a change and led to what he considered his third most important achievement in the field of health. He was asked to join an AIDS management group and became Director of the Zambian Ministry of Health AIDS Counselling Services Unit. Crash training programmes with some elements of counselling were developed and were adopted by many organisations within and outside Zambia, while Haworth himself became deeply involved in many HIV-related projects, the most important concerning couples' counselling, as well as the long-term monitoring and testing of discordant couples drawn from over 35000 couples recruited. As a member of the board of an NGO he had set up, in response to the AIDS epidemic and as National President of the Zambia Red Cross Society, he was soon involved in the plight of children (on the streets, as victims of abuse and at risk of acquiring HIV). He took part in a series of studies and helped set up a 'one stop' specialist unit for victims of child sexual abuse at the teaching hospital. He was one of the five founder members of the Family Health Trust. He acted as Chair, ensuring that the organisation would meet the needs of orphans and vulnerable children and women, and that people living with HIV/AIDS were well looked after.

Alan had some special assignments requested of him, first in Zambia where he advised on the approach to the members of a religious cult who had engaged in bloody fighting against the new government. Then, in Congo, he was asked to advise on the possibility of accepting as refugees into Zambia 'boy 
soldiers' who, with a group of mercenaries, had rebelled against Mobutu. Since they were currently under siege by the Congolese National Army, Haworth found himself under fire, looking after wounded rebels. He reported how he found this less stressful than being caught up in subsequent diplomatic shenanigans. He remained in close contact with 'freedom fighters' from South Africa and Zimbabwe and did consultancies in Mozambique and Liberia on a WHO mission, where he was briefly hijacked by a group of warlord Charles Taylor's soldiers. Throughout his professional life, he seemed to be on the fringes of violence, having once been within seconds of being lynched himself. This experience gave him confidence to know when to intervene, and he certainly prevented at least one other lynching. Called to see a close friend with a serious gunshot wound to the head in a third assassination attempt, he met the former President of Zambia, Kenneth Kaunda, who showed him his own linear graze made by a bullet across his scalp incurred in the same episode.

Haworth received public honours both in the UK and in Zambia. In the UK, he was awarded the OBE for services to medicine. He was made a Grand Commander of Distinguished Service by the President of Zambia in recognition of his services to psychiatry.

Alan Haworth came from an extremely modest background. His parents had both left school at the age of 13 , his father to work as a cotton spinner and his mother as a seamstress. Brought up on a council estate in Blackburn, he won a place at the local grammar school. Then, after National Service in the RAF, he studied medicine at Cambridge and the London Hospital. While still a medical student, he had offered to become a missionary and was sent to work in Northern Rhodesia (now Zambia).

Early in his career, while working on prison medical duties, he had several conversations with Zambia's future first president (Kenneth Kaunda), then under detention, and these had a significant influence on his future career.

He never married. However, in 1979, following the tragic death of his cook of 17 years, he took over the care of the widow and her seven children. They became his adopted family. Almost 40 years later, the grandchildren and greatgrandchildren of this family claimed that even if he looked different, as far as they were concerned, he was their real grandparent.

Alan's activities began to be curtailed in 2013, owing to ill health, and he returned to Blackburn, where he had been brought up. He had a passion for classical music and spent many long hours in his final years attending the Leeds Piano Competition.

Alan will be remembered as he wished, as a loving grandfather and uncle by his English family, and as a kindly, caring and understanding doctor by his patients. His many former students think of him with affection and respect.

\section{Reference}

1 Haworth A. Psychiatry in Zambia. Bull R Coll Psychiatr 1988; 12(4): 127-9.

Chris Haworth

doi:10.1192/bjb.2018.27

(c) The Author 2018. This is an Open Access article, distributed under the terms of the Creative Commons Attribution-NonCommercial-NoDerivatives licence (http://creativecommons.org/licenses/by-nc-nd/4.0/), which permits non-commercial re-use, distribution, and reproduction in any medium, provided the original work is unaltered and is properly cited. The written permission of Cambridge University Press must be obtained for commercial re-use or in order to create a derivative work. 